\title{
On the Estimation of Sweep Area of Sweeping Trammel Net (Kogisasiami)*
}

\author{
Kô MATUda and Takeru Kitahara**
}

(Received April 2, 1967)

The sweep area of sweeping trammel net ${ }^{11}$ must be known in order to investigate its catch efficiency, which is defined as the ratio of the capture per unit operation to the living fish stock within the region swept by the operation. In the sweeping trammel net fishery, there have appeared no researches in this field, as far as the authors are aware.

The present paper contains the discussions on sweep area of the sweeping trammel net on the basis of the field experiment performed off Hamada, Shimane Prefecture, during the summer of 1966 . This experiment was undertaken to deduce an experimental relation to express the sweep area by the size of net, the duration of towing and the power of engine.

\section{Experimental}

Fishing gear: In the present experiment, two types, $A$ and $B$, of trammel net were employed. The details of the type $\mathrm{A}$ are as follows.

Inner webbing: twine; nylon 210 denier 3 strands, $0.04 \mathrm{~mm}$ in diameter, mesh size; $60 \mathrm{~mm}$ in stretched measure, 50 meshes in depth.

Outer webbing: twine; nylon, 210 denier 6 strands, $0.06 \mathrm{~mm}$ in diameter, mesh size, $360 \mathrm{~mm}$ in stretched measure, 5 meshes in depth.

Float line: polyethylene, $6 \mathrm{~mm}$ in diameter, $43.6 \mathrm{~m}$ in length.

Lead line: $\quad$ pylyethylene, $6 \mathrm{~mm}$ in diameter, $45.5 \mathrm{~m}$ in length.

Float: $\quad$ plastics, $25 \mathrm{~mm}$ in diameter, $82.5 \mathrm{~g}$ in buoyancy, at regular intervals of $120 \mathrm{~cm}$ along the float line.

Sinker: $\quad$ terra-cotta, $25 \mathrm{~mm}$ in diameter, $37.5 \mathrm{~g}$ in air, at regular intervals of $37 \mathrm{~cm}$ along the lead line.

The other type B is similar to the type A, except that the mesh size of inner webbing is $75 \mathrm{~mm}$ in stretched measure. Of ten shackles used in the experiment, seven shackles are of type A, and the rest are of type B. Two boats engaged in the experiment are of same type of 3 gross tons with a 14 horse power Diesel engine. The other accessories of this gear are illustrated diagrammatically in Fig. 1.

* An outline of this article was presented to the autumn meeting of Japanese Society of Scientific Fisheries, Fukuyama, October 8, 1966.

** Department of Fisheries, University of Kyoto, Maizuru.（松田 㛺 - 北原 武, 京都大学農学 部水産学教室) 
Method: From the operation No. 1 to No. 5, the type of net, A and B, were arranged as shown in Fig. 1. In No. 6 and No. 7, the experiments were carried out

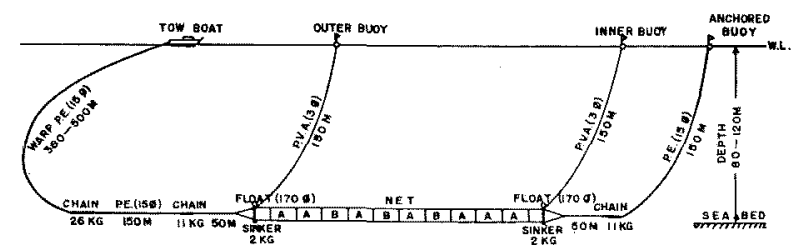

Fig. 1. Diagramatic sketch of sweeping trammel net in operation. The arrangement of net shows the case of the operation No. 1 to No. 5 .

in condition that both ends of the shackles were taken off from the above arrangement, and in No. 8 and No. 9, more one shackle was taken off from each end.

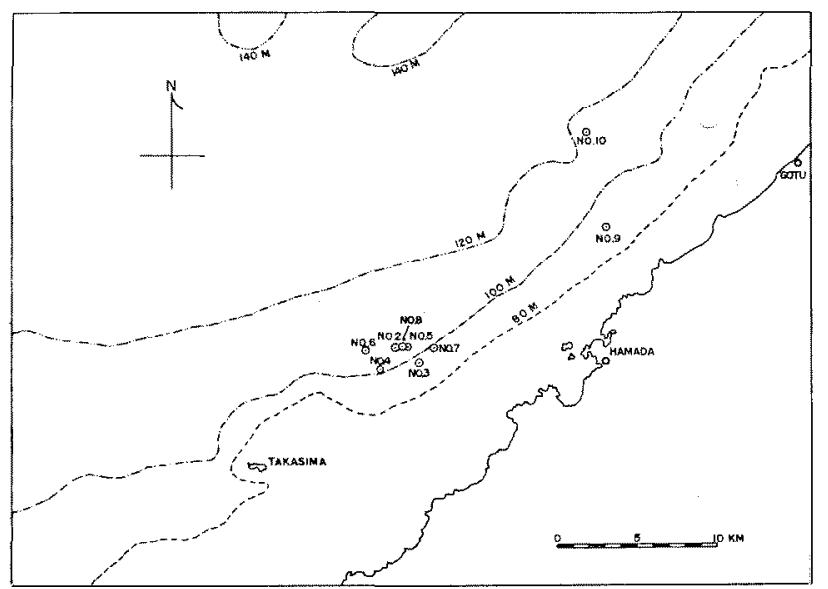

Fig. 2. Chart showing operation location, operation numbers, and contours.

This experimental area is shown in Fig. 2. This area known to be a good branquillos fishing ground, is muddy bottom and from 80 to $120 \mathrm{~m}$ deep. The numbers in Fig. 2 show the order of operations. The method of operation employed here was the same fashion to that in Wakasa Bay ${ }^{11}$. This is the original method in operation of the sweeping trammel net: The one end of net is anchored at a point of the bottom, and the other is towed by a boat so as to set a circular course with respect to the anchored end. But only the operation No. 5 was made according to the method at Shimane or Ehime Prefecture; the towing end is towed in a semi-circular course, then this towing end is anchored and fixed, then the previous anchored end is picked up and towed counterwise to the same manner, and this process is repeated several times, though in the present operation it was made twice. 
The position of the boat was determined by the following method: Choose three clearly visible objects, such as lighthouse, mountaintop, small island, in the range of about $10 \mathrm{~km}$ from the boat, two angles between them were measured aboard with sextant at an interval of 15 minutes. The position of anchored buoy was determined by the same method on a boat which always followed closely after the buoy. In order to show the position of both ends of the net, thin vinilon twines, $150 \mathrm{~m}$ long, were attached to the respective net ends. Then buoys with red flags were tied to the upper ends of these twines. Their positions were also determined with sextant from both of the boats.

The tension acting on the warp was measured with $500 \mathrm{~kg}$ spring balance. The declination of warp, the wind speed and direction were also measured in the usual manner. Various experimental conditions are shown in Table 1.

Table 1. Experimental conditions.

\begin{tabular}{|c|c|c|c|c|c|c|c|c|}
\hline $\begin{array}{l}\text { Operation } \\
\text { No. }\end{array}$ & Date & $\begin{array}{c}\text { Length } \\
\text { of net } \\
(\mathrm{m})\end{array}$ & $\begin{array}{c}\text { Number } \\
\text { of } \\
\text { shackle }\end{array}$ & $\begin{array}{l}\text { Length } \\
\text { of warp } \\
(\mathrm{m})\end{array}$ & $\begin{array}{c}\text { Area of } \\
\text { net } \\
\left(\mathrm{m}^{2}\right)\end{array}$ & $\begin{array}{l}\text { Direction } \\
\text { of } \\
\text { rotation }\end{array}$ & $\begin{array}{c}\text { Wind } \\
\text { Direction }\end{array}$ & $\begin{array}{l}\text { Wind } \\
\text { speed } \\
(\mathrm{m} / \mathrm{sec})\end{array}$ \\
\hline 2 & $7-23$ & 436 & 10 & 706 & 872 & $A^{*}$ & $\mathrm{~S}$ & 4.3 \\
\hline 3 & $"$ & $"$ & $"$ & $"$ & $"$ & " & W & 5.1 \\
\hline 4 & $7-24$ & " & $"$ & $"$ & $n$ & $\mathrm{C} * *$ & SW & 4.1 \\
\hline 5 & $"$ & " & " & " & " & $\ldots$ & W SW & 4.2 \\
\hline $5-1$ & " & $"$ & $n$ & " & " & $\mathrm{A}$ & $"$ & 4.2 \\
\hline $5-2$ & " & " & $"$ & " & " & $\mathrm{C}$ & " & 4.1 \\
\hline 6 & $7-25$ & 354 & 8 & " & 708 & A & SW & 4.0 \\
\hline 7 & " & $"$ & $" \prime$ & $"$ & $"$ & $\mathrm{C}$ & W & 4.4 \\
\hline 8 & $7-29$ & 268 & 6 & 584 & 536 & $\mathrm{~A}$ & S SW & 2.7 \\
\hline 9 & " & " & $n$ & $"$ & $"$ & $"$ & NW & 2.8 \\
\hline
\end{tabular}

* Anticlockwise.

** Clockwise.

\section{Results and Discussion}

The accuracy of sextant reading was within the range of 10 seconds, and the difference in time to read two angles was kept in the range of 30 seconds. Taking these circumstances into account, the error in measuring the positions was found to be within $50 \mathrm{~m}$. All positions thus determined, of both boats and both ends of the net, can be plotted on a chart. Then, drawing a smooth curve to fit by eye to these points, the locus of movement of the gear is obtained. Fig. 3 shows examples of various types of operations, in which the marks $\odot$, $\odot$, and $\bigcirc$ represent observed points of the two boat, outer, and inner ends of the net, respectively. The marks $\mathrm{S}$, and $\mathrm{F}$, denote the points in which the net is begun and finished to tow, respectively. As the towing operation No. 5 was made according to the method of Shima- 
ne or Ehime, the first half course of operation is shown with a set of marks $S_{1}$ and $F_{1}$, and the later with $S_{2}$ and $F_{2}$ as shown in Fig. 3-B. In these figures, the broken

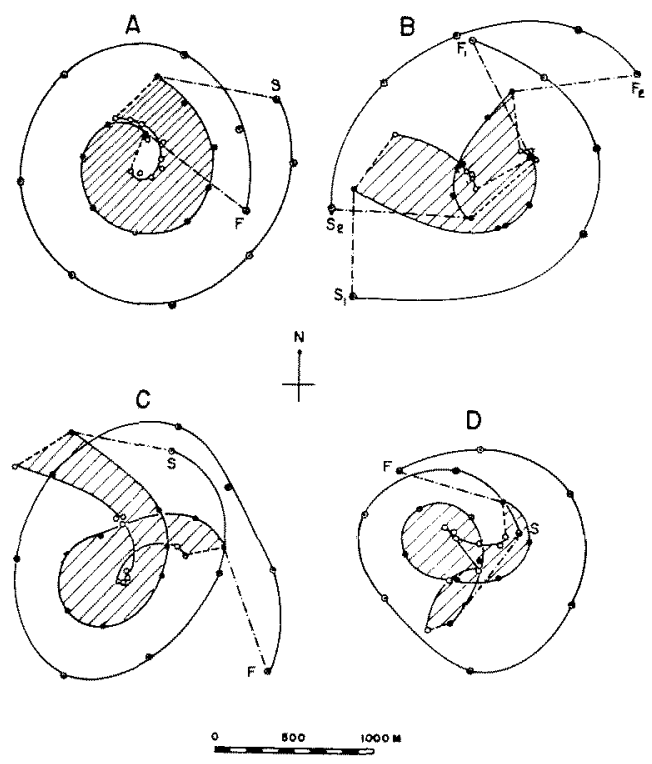

Fig. 3. Examples of operation types. The operation No. 4: A, No. 5: B, No. 7: C, No. 9: D. Hatched parts indicate sweep area. and the dotted straight lines indicate the approximate position of the net and the warp, respectively, at the beginning and final stage of towing.

The mean towing speed of boat is obtained as the towed distance divided by its duration. Here, the towed distance means the total length along which the tow boat moved from the point $S$ to $F$, and the duration is total time elapsed during the process. The sweep area is defined as the total area enclosed with the lines of net, at the beginning and final stage of towing, and the loci drawn by its both ends, as shown by the hatched parts in Fig. 3 . The observed points of the net end, however, do not always show the true position. Because the buoy line attached to the net end is not equal to the depth at the fishing ground. For instance, the depth being $100 \mathrm{~m}$, since the buoy line employed is $150 \mathrm{~m}$ long, the maximum difference in the horizontal distance between

Table 2. Results obtained in this experiment.

\begin{tabular}{c|c|c|c|c|c|c|c}
\hline \hline $\begin{array}{c}\text { Operation } \\
\text { No. }\end{array}$ & $\begin{array}{c}\text { Sweep } \\
\text { area* } \\
\left(q^{\prime} \mathrm{km}^{2}\right)\end{array}$ & $\begin{array}{c}\text { Tension } \\
\text { in warp** } \\
(T \mathrm{~kg})\end{array}$ & $\begin{array}{c}\text { Declina- } \\
\text { tion of } \\
\text { warp** } \\
\left(\alpha^{\circ}\right)\end{array}$ & $\begin{array}{c}\text { Resis- } \\
\text { tance } \\
\text { of net* } \\
(R \mathrm{~kg})\end{array}$ & $\begin{array}{c}\text { Duration } \\
\text { of } \\
\text { towing** } \\
(t \text { sec })\end{array}$ & $\begin{array}{c}\text { Towed } \\
\text { distance* } \\
\left(l_{s} \mathrm{~m}\right)\end{array}$ & $\begin{array}{c}\text { Towing } \\
\text { speed* } \\
(v \mathrm{~m} / \mathrm{sec})\end{array}$ \\
\hline 2 & 0.349 & 121.1 & 9.38 & 119.5 & 4500 & 3230 & 0.718 \\
3 & 0.525 & 147.6 & 8.57 & 145.9 & 7620 & 5770 & 0.758 \\
4 & 0.534 & 112.4 & 5.50 & 111.9 & 8100 & 5780 & 0.714 \\
5 & 0.593 & 120.9 & $\ldots$ & 119.8 & 7800 & 5670 & 0.727 \\
$5-1$ & 0.413 & 122.4 & 9.00 & 120.9 & 4200 & 3100 & 0.738 \\
$5-2$ & 0.180 & 119.4 & 6.40 & 118.7 & 3600 & 2580 & 0.715 \\
6 & 0.300 & 115.1 & 9.10 & 113.6 & 8100 & 5890 & 0.728 \\
7 & 0.654 & 109.0 & 4.63 & 108.6 & 8100 & 6290 & 0.777 \\
9 & 0.301 & 88.1 & 9.43 & 86.9 & 6300 & 4800 & 0.761 \\
\hline
\end{tabular}

* Estimated values.

** Observed values. 
the true and observed positions would become about $110 \mathrm{~m}$, even if the location of the buoy was measured exactly. Since, however, these deviations would occur in the same manner to both ends, it is supposed that the area defined above is nearly equal to the true value. The results obtained are tabulated in Table 2.

Consider that a tow boat moves an arc distance $l_{\mathrm{s}}$ along a circular course of radius of rotation $r$ with respect to a center point, then the sector area enclosed by the locus of the boat is $r l_{s} / 2$. Assuming that the length of net $l$ is proportional to the radius $r$, the sweep area $q^{\prime}$ is proportional to $l_{s} l$. In Fig. 4 , the observed values of the sweep area $q^{\prime}$ are plotted against the values of $l_{s} l$. From this, both

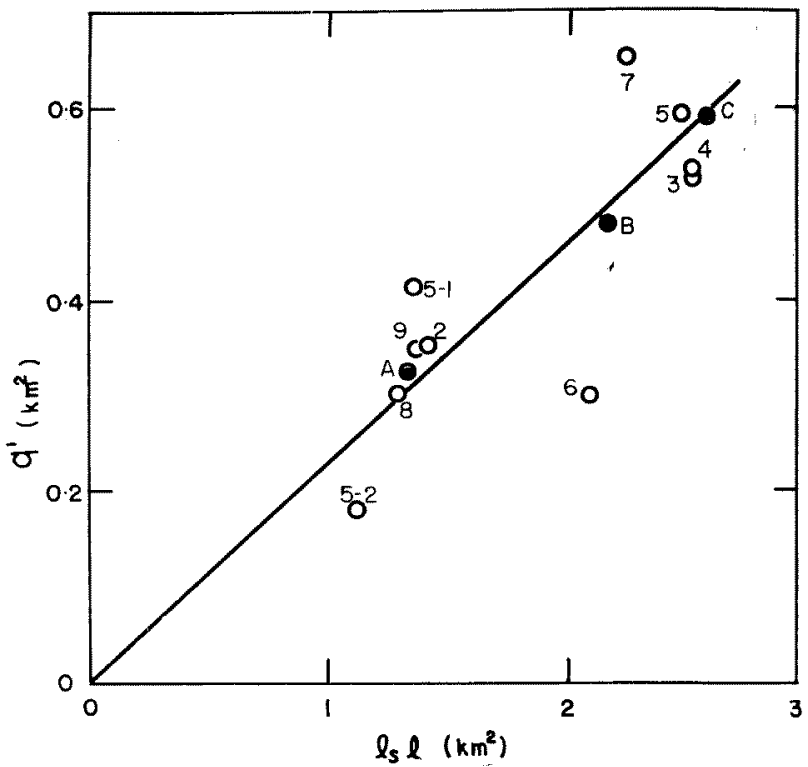

Fig. 4. Proportional relationship between $l_{s} l$ and sweep area $q^{\prime}$. Figures indicate operation number, and A, B and $\mathrm{C}$, respectively, the mean value of sweed area in 6,8 and 10 shackles.

values seem to be kept a proportional relationship. Since the towed distance $l_{s}$ of the boat equals the product of the towing speed $v$ and the duration of towing $t$, we have

$$
q^{\prime}=k_{0} l v t \text {, }
$$

where $k_{0}$ is the coefficient of proportionality. From Table 3 , the mean value of $k_{0}$ is

Table 3. Numerical values of proportional coefficient

\begin{tabular}{c|c|c|c|c}
\hline $\begin{array}{c}\text { Operation } \\
\text { No. }\end{array}$ & $\begin{array}{c}k_{0} \\
-\end{array}$ & $\begin{array}{c}k_{1} \\
\left(\mathrm{~kg} \mathrm{sec}^{2} / \mathrm{m}^{4}\right)\end{array}$ & $\begin{array}{c}k_{2} \\
(\text { h.p. sec/kg m) }\end{array}$ & $\begin{array}{c}k_{4} \\
\left(\mathrm{~m}^{5 / 3} \mathrm{~h} . \mathrm{p} .1 / 3 \mathrm{sec}\right)\end{array}$ \\
\hline 2 & 0.248 & 0.266 & 0.163 & 0.663 \\
3 & 0.208 & 0.291 & 0.127 & 0.590 \\
4 & 0.212 & 0.252 & 0.175 & 0.564 \\
5 & 0.240 & 0.260 & 0.161 & 0.651 \\
6 & 0.144 & 0.303 & 0.169 & 0.387 \\
7 & 0.293 & 0.254 & 0.166 & 0.844 \\
8 & 0.233 & 0.279 & 0.212 & 0.601 \\
9 & 0.256 & 0.358 & 0.210 & 0.607 \\
\hline
\end{tabular}


obtained to be nearly equal to 0.23 under the present circumstances.

This value of $k_{0}$ will be applicable to the analysis of fishery resource of sweeping trammel net, so far as the mode of operation is not so different from the present experiment. Therefore, if the value of $l$, and the product $t v$ or $l_{s}$ are known, we can estimate $q^{\prime}$ by Eq. (1). The length of net and the duration of towing may be obtained from fishery records, but the towing speed or the towed distance would be difficult to be known. Since towing speed depends on the power of engine installed in the boat and on the size of the net used, we shall try to express the towing speed by these two factors.

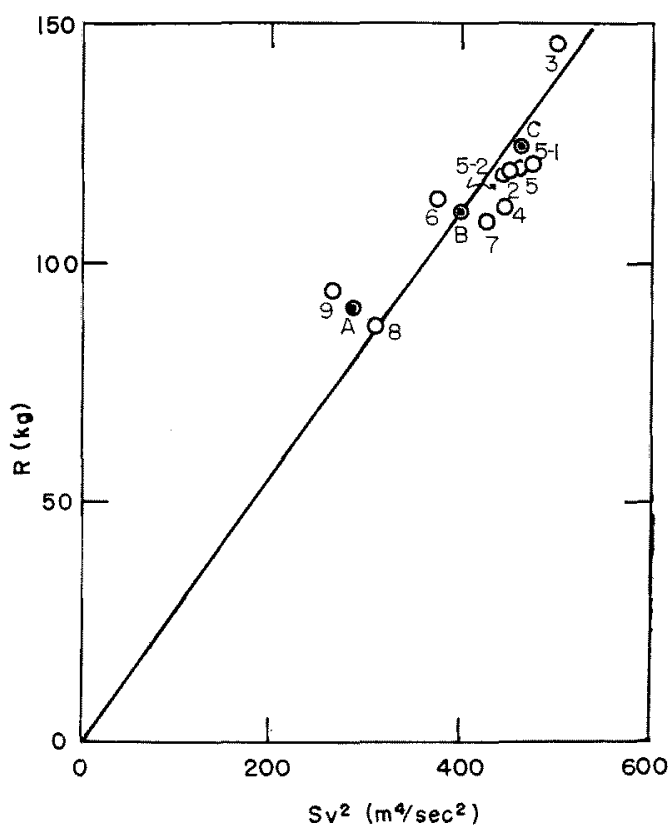

Fig. 5. Proportional relationship between $S v^{2}$ and resistance $R$.
Now, consider the case in which a boat with a engine of $P$ h.p. towes a net of area $S$ at a speed $v$. The resistance $R$ of net is proportional to the area of net and proportional to square of towing speed, provided that the hydrodynamic resistance of warp is negligibly small as compared with total resistance of the net. The observed values of $R$ are plotted against the values of $S v^{2}$ as shown in Fig. 5, which shows that this is in linear relation. Here, $R$ is calculated by the relation $R=T \cos \alpha, T$ and $\alpha$ being the tension and the declination of warp, respectively. Thus we have

$$
R=k_{1} S v^{2}
$$

where $k_{1}$ is a coefficient and is shown numerically in Table 3.

On the other hand, the effective engine power $P_{E}$ may be proportional to the value of $R v$, if the engine revolution is kept always constant during full course of towing. We have no researches on the relation between the nominal engine capacity $P$ and the effective engine power $P_{a}$ for such a small engine, from 3 to 35 h.p., as employed in this fishery. In the case of large trawler, KoYAMA ${ }^{2-4)}$ reported that $P_{B}$ is proportional to 1.7 powers of $P$ in the range $300<P<2000 \mathrm{~h} . \mathrm{p}$., and that $P_{B}$ is directly proportional to $P$ in $2000<P<3500$ h.p. For the sake of simplicity, assume that $P_{\theta}$ is proportional to $P$, and neglect the resistance acting on the boat as compared with that of net, we have

$$
P=k_{2} R v,
$$

where $k_{2}$ is a constant coefficient. In the present experiment, since the engine re- 
volution was kept always constant during the experiment, the relation (3) holds. From Table 3, the values of $k_{2}$ seem to be nearly constant except the operation No. 3 , No. 8 , and No. 9. These discrepancies are supposed to be dependent largely upon the wind.

Eliminating $R$ from Eqs. (2) and (3),

$$
v=k_{3} \sqrt[3]{P / S},
$$

where $k_{3}=\left(k_{1} k_{2}\right)^{-1 / 3}$. Then, substituting Eq. (4) into Eq. (1), we obtain

$$
q^{\prime}=k_{4} l t \sqrt[3]{P / S},
$$

where $k_{4}=k_{0} k_{3}$. Letting $h$ be the depth of net, since $S=l h$, Eq. (5) is reduced to

$$
q^{\prime}=k_{4} t \sqrt[3]{l^{2} P / h} .
$$

The values of $k_{4}$ are calculated on the basis of data listed in Tables 1 and 2 , and are shown in Table 3 using the units; meter, second and horse power. While it seems to be nearly constant irrespective of the variety of operational conditions, we may notice some unusual values in operation No. 6 and 7. If we take the mean values for operations in which the same number of net shackles, i.e., 6, 8 and 10 shackles, were employed, the value $k_{4}$ can be regarded as constant, and are 0.606 , 0.616 and 0.617 , respectively. Taking the field conditions in the experiment into account, these results seem to be considerably accorded with the theory.

This equation and the mean value of $k_{4}$ throughout this study have been applied to the investigation concerning the catch efficiency of sweeping trammel net in the brambuillos fishery in Wakasa Bay, and the results will be presented in a succeeding paper.

The authors wish to express their deep gratitude to Professor T. Kawakami, for his guidance. Thanks are also due to Messrs. S. Katô and S. KoJima, Shimane Prefectural Fisheries Experimental Station, for their helps of technical services. They are indebted to Messrs. M. SHINODA and Y. TANAKA for technical assistance.

\section{References}

1) K. Matuda: This Bull., 29, 135 138, (1966).

2) T. Koyama: Bull. Tokai. Reg. Res. Lab., No. 34, 75 81, (1962).

3) T. Koyama: ibid., No. 43, 13 71, (1965).

4) T. Koyama: This Bull., 32, 475 479, (1966). 